\title{
Population densities and diurnal activity pattern of the Indian Roller Coracias benghalensis (Aves: Coraciiformes) in Nagapattinam District, Tamil Nadu, India
}

\author{
S. Asokan ${ }^{1}$, A. Mohamed Samsoor Ali ${ }^{2}$, R. Manikannan ${ }^{3} \&$ G. Thomas Nithiyanandam ${ }^{4}$ \\ ${ }^{1}$ Associate Professor, ${ }^{3}$ Lecturer \& ${ }^{4}$ PhD Research Scholar, PG \& Research Department of Zoology and Wildlife Biology, A.V.C. \\ College (Autonomous), Mannampandal, Tamil Nadu 609305, India \\ ${ }^{2}$ New \# 12, Old \# 3/10, New Street, Kollapuram, Tiruvarur District, Tamil Nadu 609608, India \\ Email: ${ }^{1}$ beeasokan@yahoo.co.in, ${ }^{2}$ amsamsoor@yahoo.co.in (corresponding author), ${ }^{3}$ manikannanr@yahoo.co.in, \\ ${ }^{4}$ kevin2008@yahoo.co.in
}

\begin{abstract}
Population densities and diurnal activity pattern of the Indian Roller were studied in Nagapattinam District over three years in different habitats. The agricultural lands supported the highest populations $\left(41 \mathrm{~km}^{-2}\right)$, followed by river banks $\left(36 \mathrm{~km}^{-2}\right)$ and social forests $\left(32 \mathrm{~km}^{-2}\right)$; populations showed yearly variations in numbers and density in all habitats. On average, birds were observed to spend most of the day scanning $(57 \%)$, with the remainder divided among feeding (16\%), flying, $(12 \%)$, preening $(10 \%)$ and resting (5\%). Some variations in activity breakdown were observed between time blocks, seasons and habitats.
\end{abstract}

Keywords: Agricultural lands, feeding, Indian Roller, population, river banks, scanning, social forests, time activity pattern.

Date of publication (online): 26 September 2010 Date of publication (print): 26 September 2010 ISSN 0974-7907 (online) | 0974-7893 (print)

Editor: C. Srinivasulu

Manuscript details:

Ms \# 02308

Received 08 September 2009

Final received 29 August 2010

Finally accepted 31 August 2010

Citation: Asokan, S., A.M.S. Ali, R. Manikannan \& G.T. Nithiyanandam (2010). Population densities and diurnal activity pattern of the Indian Roller Coracias benghalensis (Aves: Coraciiformes) in Nagapattinam District, Tamil Nadu, India. Journal of Threatened Taxa 2(10): 1185-1191.

Copyright: (c) S. Asokan, A. Mohamed Samsoor Ali, R. Manikannan \& G. Thomas Nithiyanandam 2010. Creative Commons Attribution 3.0 Unported License. JoTT allows unrestricted use of this article in any medium for non-profit purposes, reproduction and distribution by providing adequate credit to the authors and the source of publication.

Author Details and Acknowledgements: see end of this article.

Author Contribution: The field study was conducted by AMSA and RM under the supervision of SA. AMSA analyzed data and wrote the manuscript and SA provided necessary suggestions during manuscript preparation

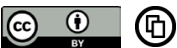

OPEN ACCESS | FREE DOWNLOAD

\section{INTRODUCTION}

The Indian Roller Coracias benghalensis, also called the Blue Jay, is a widespread resident in India, Iraq, Iran, Pakistan, Burma, Southeast Asia, Tibet and parts of China (Ali \& Ripley 1983). It is a stocky bird about 26-27 $\mathrm{cm}$ long and inconspicuous when resting, but as it takes flight the primaries and secondaries show bright shades of blue (Rasmussen \& Anderton 2005). During the breeding season males perform ornate sexual displays as they fly upward, then roll and fall through the air wildly flapping their wings and screaming harshly, which is how they earned the name roller. Rollers are not migratory but do show some seasonal movement. Their main habitat is cultivated areas, thin forest and grassland, and their diet consists of a variety of insects (Asokan et al. 2009). They may be found in farms and in cities at lower elevations and can be often seen perched on roadside electric wires. Two subspecies are usually recognized viz., Coracias benghalensis benghalensis and Coracias benghalensis affinis. The nominate form is found from West Asia (Iraq, Arabia) to Bangladesh and north of the Vindhyas ranges. The race affinis is found in northeastern India and Southeast Asia (Thailand, Yunnan and Indochina). Some information on the ecology of this species was available (Gupta 1976; Mathew et al. 1978; Panicker 1978; Santharam 1996; Sivakumaran \& Thiyagesan 2003), but detailed ecological studies were lacking.

Estimations of population size can provide a strong foundation for the conservation of bird species. The general concept that birds select habitats based on vegetation structure or habitat physiognomy has been expressed by some researchers (Odum 1950; James 1971; Svardson 1993). Avian population densities can be influenced by the singular or interactive influences of predation, intra and interspecific resource competition, parasites, diseases, habitat availability and weather (Andrewartha \& Birch 1954; Begon \& Mortimer 1986). The magnitude of the influence of these factors may vary in importance according to geographical area, food habits and migratory status of the birds (van Balen 1980). 
Activity time budget data are useful in studying the ecological, behavioural and physiological aspects of birds (Verner 1965; Evers 1994; Lee 1997; Hamilton et al. 2002; Jonsson \& Afton 2006), to develop appropriate survey techniques and ultimately to manage threatened or endangered species. Time-activity budgets reflect a combination of factors including individual physical condition, social structure and environmental conditions (Paulus 1988). Information on diurnal activity patterns of the Indian bird species is scanty (Mahabal 1991; Natarajan 1991; Ramachandran 1998; Sivakumaran \& Thiyagesan 2003). This present study investigates the factors that influence the population fluctuations and diurnal activity patterns of Indian Roller in different time blocks, seasons and habitats in Nagapattinam District.

\section{MATERIALS AND METHODS}

Study area: The study was conducted in three villages: Mannamandal, Manakudi and Thiruvalanagadu of Nagapattinam District (18018'N \& 79050'E), Tamil Nadu, India between 2004 and 2006. The study area is dominated by wet agricultural lands irrigated by the River Cauvery and its tributaries. Woody vegetation is sparse in the form of groves and roadside trees. The predominant wood plant species found in the study area are Cocos nucifera, Borassus flabellifer, Madhuca indica, Mangifera indica, Enterolobium saman, Tamarindus indicus, Ficus benghalensis, Ficus religiosa, Thespesia populnea, Acacia arabica, Odina wodier and Azadirachta indica. Important shrub species are Prosopis juliflora, Jatropha glandulifera, Adhathoda vasica. Plantations of Casuarina equisetifolia, Tectona grandis and Bamboosa arundinacea are also found in the study area.

Study habitats: The present study was carried out in three different habitats: agricultural lands, river banks and social forestry plantations. The agricultural lands are under cultivation of paddy, sugarcane and plantain; river banks are characterized by the predominance of riverside vegetation and the social forestry plantations include a variety of village woodlots planted with casuarina, bamboo, teak, and eucalyptus.

Population density: The line transect method described by Gaston (1975) was followed to study the population density of Indian Roller. Though many methods of avian population enumeration are available, the line transect method is preferred because of the nature of the study area which is predominantly open with sparse distribution of trees. In each habitat three one kilometer long transects were laid and birds censused within a $50 \mathrm{~m}$ belt on either side of transect. The data so obtained were extrapolated to estimate the bird densities as number per square $\mathrm{km}$ using the following formula:

$$
D=\text { Number of birds } / 2 \times L \times W
$$

where, $L=$ Length of transect and $W=1 / 2$ width of transect.

All census operations were carried out immediately after sunrise and normally from 0600 to $0800 \mathrm{hr}$. Double counting was avoided by noting the direction of movements of the birds. The census was done at the rate of 0.75 to $1.00 \mathrm{~km} / \mathrm{hr}$. Counting of birds was avoided on cloudy, rainy and windy days. Censuses were carried out fortnightly during the study period in all the three habitats.

Time activity pattern: Data was collected twice monthly from 2004 to 2006 in all three habitats. Each day was divided into four time blocks: early morning (0600-0900 hr), late morning (0900-1200 hr), midday or afternoon (1200-1500 hr) and late evening (1500-1800 hr). The study season was divided in the following manner: post-monsoon (January-March), summer (April-June), pre-monsoon (July-September) and monsoon (OctoberDecember). We used focal animal sampling method (Altmann 1974) to studying time activity patterns of Indian Roller. Each observation session started with the choice of a focal individual bird, by selecting the closest readily visible individual. Possibly a single bird was observed throughout the day, if bird was out of sight another bird was selected wherever closest to the observer (Altman 1974). Observations were conducted free from precipitation and strong winds. The focal individual was observed with $7 \mathrm{x}$ 50 field binoculars continuously for 15 minutes followed by a 5-minute break. In one hour three such samples were taken. The duration of each behavior was recorded on the electronic stop watch. In each year we collected data on behavior of Indian Roller for 144 hours and totally for 432 hours during three years for each habitat. The monthwise time spent in different activities was calculated and from these values the percentage time spent for each activity during different times on the day was estimated. The activities are divided into five major categories:

(i) Scanning: perched in an upright position scanning surroundings actively.

(ii) Flying: in flight, often in pursuit on prey.

(iii) Feeding: capturing prey and swallowing into the buccal chamber.

(iv) Preening: comfort movements including feather shaking, wing flapping, bill cleaning, bill scratching, body shaking and tail shaking.

(v) Resting: perched sleeping or dozing with head retracted and eyes closed.

Statistical analysis: One-way ANOVA was used to compare mean seasonal and yearly population densities. Two-way ANOVA was used to compare mean population density between habitats and seasons. Kruskal-Wallis test was performed to compare activities between time blocks, seasons and habitats. All the analyses was performed using MINITAB statistical software. Significance of all tests were assessed at $a=0.05$. Results of the above analysis were interpreted using standard statistical 
procedures (Sokal \& Rohlf 1981).

\section{RESULTS}

Mean population density of Indian Roller varied from $22 \mathrm{~km}^{-2}$ (monsoon 2004 at the river banks) to $41 \mathrm{~km}^{-2}$ (postmonsoon 2004 at the agricultural lands). In general the agricultural lands supported relatively higher numbers of birds, followed by the river banks and social forests (Figs. 1,2 \& 3). Year-wise mean densities (across all seasons) in the three habitats are given in Table 1. The higher densities in agricultural lands, river banks and social forests were recorded during $2004\left(35 \mathrm{~km}^{-2}\right), 2005\left(31 \mathrm{~km}^{-2}\right)$ and $2006\left(27 \mathrm{~km}^{-2}\right)$ respectively. Year-wise differences were not statistically significant (Table 1), but population densities were significantly lower during monsoon in all habitats (Table 2) and density differed significantly between habitats in all years (Table 3 ).

Scanning was the most important diurnal activity (57.2 $\pm 5.41 \%)$, followed by feeding $(16.2 \pm 4.09 \%)$, flying $(11.6 \pm 3.97 \%)$, preening $(9.9 \pm 2.54 \%)$ and resting (5.1 \pm $1.84 \%$ ) (Fig. 4). There was a strong relationship between time allocated to each activity and time of day (Table 4). Feeding activity varied among daylight hours and was higher in the morning $(26.4 \pm 5.40 \%)$ and evening (31.8 $\pm 0.54 \%)$ than that of midday $(11.5 \pm 0.66 \%$, Table 3$)$. The peaks in flying were similar to the peaks in feeding in all the time blocks of a day and scanning, preening and resting were higher in the midday (Table 4).

Percent time spent in flying, feeding and resting differed significantly by seasons (Table 5). The Indian Roller fed least in monsoon $(10.6 \pm 4.56 \%)$ and most in summer $(26.2 \pm 3.71 \%)$. Scanning was the most prevalent activity in each season and was greatest in monsoon $(70.1 \pm 4.01$ $\%)$. Preening activities in pre-monsoon and monsoon exceeded those in post-monsoon or summer. Flying and resting were greatest in summer and post-monsoon respectively (Table 5).

Time allocated to different activities except flying varied significantly according to type of habitat use (Table 6). Percentage of time spent on feeding were highest in agricultural lands $(23.7 \pm 3.29 \%)$ and lowest in social forestry plantations $(17.6 \pm 3.54 \%)$. Scanning usually was higher in social forests and time spent in flying, preening and resting was more or less similar to all the habitat types (Table 6).

\section{DISCUSSION}

Indian Roller densities showed habitat-wise variations with the agricultural lands generally supporting highest populations followed by river banks and social forests. According to Lack (1937), terrestrial animals seek their habitats rather than dispersing randomly and birds are no

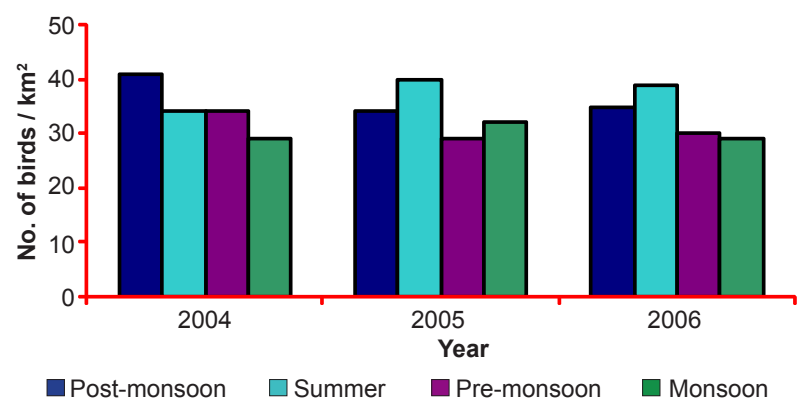

Figure 1. Habitat-wise variations in the density of the Indian Roller in agricultural lands from 2004 to 2006

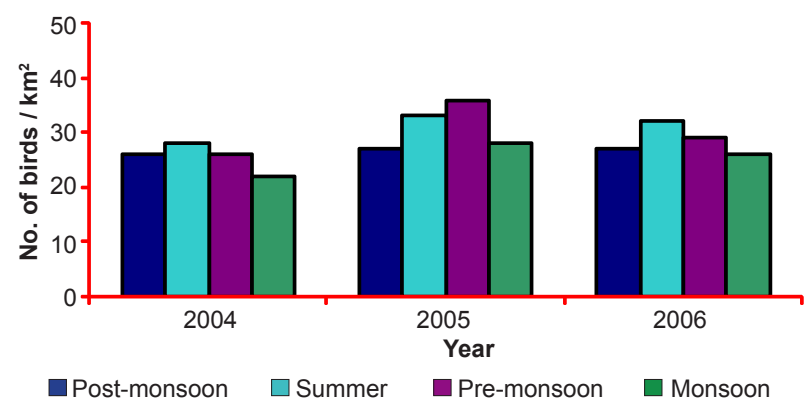

Figure 2. Habitat-wise variations in the density of the Indian Roller in river banks from 2004 to 2006

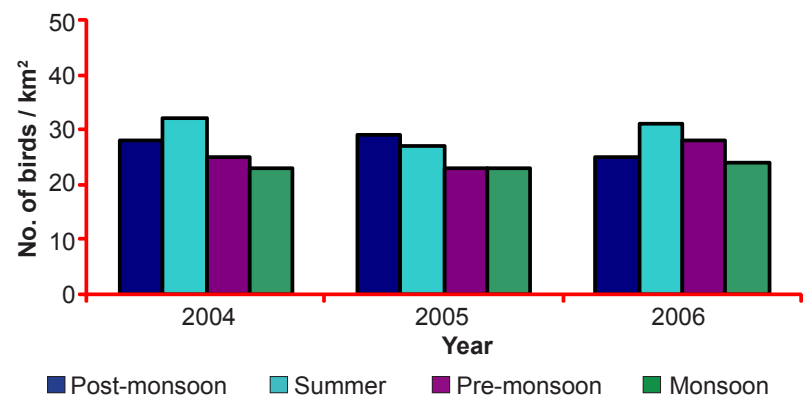

Figure 3. Habitat-wise variations in the density of the Indian Roller in social forests from 2004 to 2006

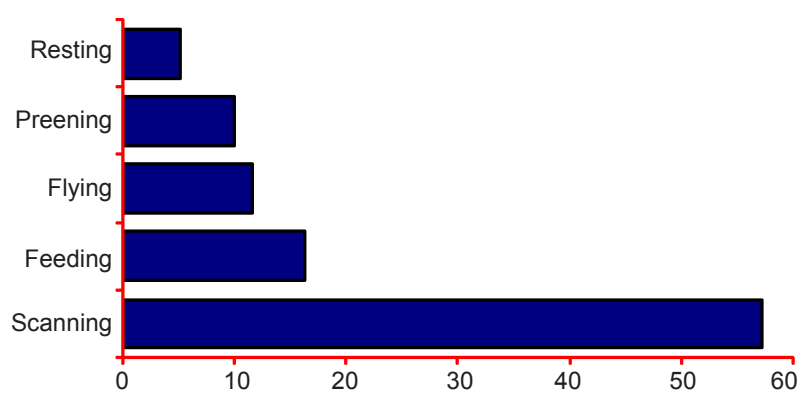

Figure 4. Overall (\%) diurnal activities of the Indian Roller 
Table 1. Yearly variations in the density of the Indian Roller in the three habitats from 2004 to 2006.

\begin{tabular}{|l|c|c|c|c|c|}
\hline \multirow{2}{*}{ Habitat } & \multicolumn{3}{|c|}{ No. of birds $/ \mathbf{~ m m}^{\mathbf{2}}$} & \multicolumn{2}{c|}{ One-way ANOVA } \\
\cline { 2 - 6 } & $\mathbf{2 0 0 4}$ & $\mathbf{2 0 0 5}$ & $\mathbf{2 0 0 6}$ & $\mathbf{F}$ & $\mathbf{p}$ \\
\hline Agricultural lands & $34 \pm 5.61$ & $35 \pm 6.01$ & $33 \pm 4.67$ & 0.113 & 0.893 \\
\hline River banks & $25 \pm 4.91$ & $31 \pm 7.98$ & $29 \pm 4.01$ & 2.475 & 0.100 \\
\hline Social forests & $23 \pm 3.78$ & $26 \pm 3.00$ & $27 \pm 3.89$ & 0.318 & 0.729 \\
\hline
\end{tabular}

Table 2. Seasonal variations in the density of the Indian Roller in the three habitats from 2004 to 2006.

\begin{tabular}{|l|c|c|c|c|}
\hline \multirow{2}{*}{ Habitat } & \multicolumn{4}{|c|}{ No. of birds / km ${ }^{2}$} \\
\cline { 2 - 5 } & Post-monsoon & Summer & Pre-monsoon & Monsoon \\
\hline Agricultural lands & $36 \pm 5.16$ & $31 \pm 4.00$ & $38 \pm 4.32$ & $30 \pm 4.64$ \\
\hline River banks & $27 \pm 1.26$ & $31 \pm 3.89$ & $30 \pm 9.86$ & $25 \pm 4.01$ \\
\hline Social forests & $26 \pm 4.35$ & $30 \pm 4.01$ & $25 \pm 3.33$ & $23 \pm 2.00$ \\
\hline
\end{tabular}

exception. The greater number of Indian Rollers at the agricultural lands might be due to relatively rich supply of insects. Lack (1966) stated that food is frequently the most important density dependent factor for birds. Sivakumaran \& Thiyagesan (2003) studied the population of Indian Roller in Mayiladuthurai and Sirkali taluks (Nagapattinam District) and they concluded that they preferred agricultural lands (50 birds $\mathrm{km}^{-2}$ ) and avoided the urban habitats. The river banks and social forests ranked second and third in the order of preference that might be due to greater vegetation densities and availability of prey. In these habitats, large well branched trees were recorded and they provided suitable nesting sites to the Indian Roller. Vegetative complexity has been shown to be strongly correlated with the structure of avian communities. Complex vegetation also aids in protection from predators. DeGraff \& Wentworth (1986) reported a strong association between the measures of tree cover and insectivorous bird densities. Tokeshi (1993) found that the structure of vegetation communities had a greater influence on the distribution of bird species. The dependence of birds on vegetation and its effect on determining the diversity of feeding, breeding and hiding possibilities for birds has been documented in numerous studies (Johnston \& Odum 1956; Emlen 1970; Holmes \& Robinson 1981; Ding et al. 1997; Asokan et al. 2003).

Seasonal variations in the density of Indian Roller were recorded among habitats with river banks and social forests showing high densities during summer and the agricultural lands during pre-monsoon season. The Indian Roller breeds during summer (April-June) in the study area and since the river banks and social forests provided suitable nesting-sites (tree holes/cavities) these habitats had high number of Indian Roller population during summer. Relatively high densities of Indian Rollers during pre-monsoon in agricultural lands might be attributed to the movement of newly recruited young ones together
Table 3. Two-way Analysis of variance (ANOVA) to investigate the population density variations in 2004, 2005 and 2006 during different seasons and habitats.

\begin{tabular}{|l|c|c|c|c|c|}
\hline \multicolumn{7}{|l|}{ Two-way Analysis of Variance for Density 2004} \\
\hline Source & DF & SS & MS & F & p \\
\hline Season & 3 & 65 & 21.67 & 3.1 & 0.111 \\
\hline Habitat & 2 & 92.67 & 46.33 & 6.62 & $0.030^{*}$ \\
\hline Error & 6 & 42 & 7 & & \\
\hline Total & 11 & 199.67 & & & \\
\hline \multicolumn{7}{|l|}{} & & & \\
\hline Two-way Analysis of Variance for Density 2005 & \\
\hline Source & DF & SS & MS & F & p \\
\hline Season & 3 & 46.25 & 15.42 & 3.94 & 0.072 \\
\hline Habitat & 2 & 73.17 & 36.58 & 9.34 & $0.014^{*}$ \\
\hline Error & 6 & 23.5 & 3.92 & & \\
\hline Total & 11 & 142.92 & & & \\
\hline \multicolumn{7}{|l|}{} & \multicolumn{5}{|l}{} \\
\hline Two-way Analysis of Variance for Density 2006 & p \\
\hline Source & DF & SS & MS & F & p \\
\hline Season & 3 & 37.58 & 12.53 & 3.92 & 0.073 \\
\hline Habitat & 2 & 87.5 & 43.75 & 13.7 & $0.006^{*}$ \\
\hline Error & 6 & 19.17 & 3.19 & & \\
\hline Total & 11 & 144.25 & & & \\
\hline
\end{tabular}

*Significantly differed $(p<0.05)$

with their parents in pursuit of insect prey, which was usually abundant in the agricultural lands. Various factors may be cited for yearly variations in bird densities viz., predation, intra and interspecific completion, parasites and diseases, habitat availability, weather, food habits and migratory status (Lancaster \& Rees 1979; Andrewartha \& Birch 1984; Menge \& Sutherland 1987; Pulliam 1988; 
Table 4. Percentage of time spent (mean \pm SD) on different activities by Indian Roller according to time of day

\begin{tabular}{|l|c|c|c|c|c|c|}
\hline \multirow{2}{*}{ Activity } & \multicolumn{7}{|c|}{ Time of Day (Hours) } \\
\cline { 2 - 7 } & $\mathbf{0 6 0 0 - 0 9 0 0}$ & $\mathbf{0 9 0 0 - 1 2 0 0}$ & $\mathbf{1 2 0 0 - 1 5 0 0}$ & $\mathbf{1 5 0 0 - 1 8 0 0}$ & $\mathbf{H}$ & $\mathbf{p}$ \\
\hline Scanning & $43.3 \pm 3.21$ & $56.1 \pm 3.30$ & $54.2 \pm 4.10$ & $35.1 \pm 3.64$ & 40.11 & $0.000^{*}$ \\
\hline Flying & $17.6 \pm 4.11$ & $9.5 \pm 1.47$ & $13.1 \pm 3.21$ & $24.5 \pm 2.14$ & 12.54 & $0.045^{*}$ \\
\hline Feeding & $26.4 \pm 5.40$ & $19.3 \pm 2.66$ & $11.5 \pm 0.66$ & $31.8 \pm 0.54$ & 148.07 & $0.000^{*}$ \\
\hline Preening & $7.6 \pm 3.21$ & $9.1 \pm 2.04$ & $10.9 \pm 1.96$ & $6.3 \pm 2.31$ & 44.63 & $0.000^{*}$ \\
\hline Resting & $5.1 \pm 1.47$ & $7.0 \pm 0.08$ & $10.3 \pm 0.78$ & $2.3 \pm 1.61$ & 118.34 & $0.000^{*}$ \\
\hline
\end{tabular}

* Differ significantly (Kruskal-Wallis test, $p<0.05)$ between time blocks

Table 5. Percentage of time spent (mean \pm SD) on different activities by Indian Roller according to season

\begin{tabular}{|l|c|c|c|c|c|c|}
\hline \multirow{2}{*}{ Activity } & \multicolumn{9}{|c|}{ Season } \\
\cline { 2 - 8 } & Post-monsoon & Summer & Pre-monsoon & Monsoon & H & p \\
\hline Scanning & $61.7 \pm 2.71$ & $48.1 \pm 3.32$ & $58.4 \pm 2.54$ & $70.1 \pm 4.01$ & 5.17 & 0.153 \\
\hline Flying & $7.1 \pm 3.01$ & $16.7 \pm 4.05$ & $8.0 \pm 3.60$ & $4.4 \pm 0.97$ & 31.3 & $0.000^{*}$ \\
\hline Feeding & $15.5 \pm 2.04$ & $26.2 \pm 3.71$ & $17.4 \pm 2.11$ & $10.6 \pm 4.56$ & 54.17 & $0.000^{*}$ \\
\hline Preening & $9.2 \pm 1.22$ & $6.5 \pm 1.94$ & $13.1 \pm 1.57$ & $13.4 \pm 4.01$ & 3.78 & 0.491 \\
\hline Resting & $6.5 \pm 1.63$ & $2.5 \pm 1.32$ & $3.1 \pm 0.99$ & $1.5 \pm 1.66$ & 20.18 & $0.000^{*}$ \\
\hline
\end{tabular}

* Differ significantly (Kruskal-Wallis test, $p<0.05)$ between seasons

Table 6. Percentage of time spent (mean \pm SD) on different activities by Indian Roller according to habitat

\begin{tabular}{|l|c|c|c|c|c|}
\hline \multirow{2}{*}{ Activity } & \multicolumn{5}{|c|}{ Habitat } \\
\cline { 2 - 6 } & Agricultural lands & River banks & Social forests & H & p \\
\hline Scanning & $44.5 \pm 5.14$ & $52.1 \pm 1.17$ & $55.1 \pm 2.65$ & 56.45 & $0.000^{*}$ \\
\hline Flying & $11.4 \pm 2.01$ & $13.1 \pm 2.66$ & $9.4 \pm 0.97$ & 8.44 & 0.614 \\
\hline Feeding & $23.7 \pm 3.29$ & $18.5 \pm 4.09$ & $17.6 \pm 3.54$ & 137.42 & $0.000^{*}$ \\
\hline Preening & $11.6 \pm 1.62$ & $9.9 \pm 2.11$ & $10.4 \pm 2.21$ & 20.13 & $0.001^{*}$ \\
\hline Resting & $8.8 \pm 0.54$ & $6.4 \pm 1.31$ & $7.5 \pm 0.65$ & 34.92 & $0.000^{*}$ \\
\hline
\end{tabular}

* Differ significantly (Kruskal-Wallis test, $p<0.05)$ between habitats

Rosenzweig 1991; Chamberlain et al. 1999).

Scanning was the most time consuming diurnal activity for Indian Roller. The Indian Roller is a sit-and-wait predator and hence was observed to spend more time in searching for food. In the study area they generally perched on electric power lines and small trees when searching for food. Earlier, Sivakumaran \& Thiyagesan (2003) reported that the Indian Roller spent majority of their time in searching for prey. Similar pattern was reported among other bird species (Ettinger \& King 1980; Losito et al. 1990; Mahabal 1991). Within the time blocks, scanning activity was greater in late morning (0900-1200 $\mathrm{hr}$ ) and midday (1200-1500 hr) and differed between time blocks. The availability of insect prey was lowest during above period and they spent additional time in searching (scanning) for prey and feeding was also comparatively lesser in the above time blocks. Seasonal pattern of scanning varied and showed a peak during monsoon
(70.1\%) and a dip during summer (48.1\%). The reason for high percentage of time spent in monsoon was due to heavy rainfall. During monsoon (October - December), the study area was affected by northeast monsoon and all the habitats were generally wet in condition and they greatly affected the distribution of insects. In post-monsoon also, due to cold temperatures, it could be expected that birds devote more time to scanning, while the reverse is true during the summer. Among habitats, scanning was lowest in agricultural lands, moderate in river banks and highest in social forests and is directly correlated with the vegetation structure, insect availability and activity and predator pressure.

Indian Roller spent $11.6 \%$ of their diurnal time in flying activities. Indian Roller flying activity differed significantly at all the time of day and seasons but not in habitats. In general the peaks in flying were similar to the peaks in feeding in all time blocks, seasons and habitats. A 
bimodal peak in the feeding pattern one during morning (0600-0900 hr) and another during evening (1500-1800 hr) was observed. Sivakumaran \& Thiyagesan (2003) stated that Indian Roller fed more during the late evening. Other birds are known to exhibit feeding maxima early in the morning and late in the evening (Frederick \& Klaas 1982; Paulus 1984; Gauthier et al. 1988; Natarajan 1991; Evers 1994; Ramachandran 1998; Rodway 1998). In summer, because of the midday heat, food is most available in the early morning. More feeding activity of Indian Roller in the late evening may reflect their need to obtain energy for overnight energetic requirements. Schartz \& Zimmerman (1971) stated that amount of time spent in feeding does reflect the effect of temperature, time of day, microhabitats and prey availability. Seasonal feeding activity indicated that Indian Roller fed more during summer $(26.2 \%)$ as compared to monsoon (10.6\%). In the study site, the food resources are generally abundant during summer and Indian Roller fed a variety of insects (grasshoppers, beetles, bugs) in year round. The amount of feeding time was significantly differed among the three habitats studied. Highest feeding activities were seen in the agricultural lands (23.7\%) followed by riverbanks $(18.5 \%)$ and social forests $(17.6 \%)$. The agricultural lands are dynamic habitats that are unpredictable in terms of insect food abundance and availability. The less time spent in river banks and social forests may be due to less insect availability, avian predator pressure and human disturbance.

Overall, the Indian Roller spent $9.9 \%$ of their diurnal time preening, which varied significantly between time blocks (high in midday and low in late evening). Preening activity was not differed significantly between seasons, but Indian Roller spent more time preening during monsoon (13.4\%) than other season. Time spent preening was generally high in all habitats, peak being observed in agricultural lands. The wings, breast and back were the body parts most often preened by Indian Roller, followed by the tail, neck, rump and feet. The most frequent comfort activities were bill scratching, feather shaking and wing flapping. Time spent to this kind of body maintenance activities were recorded in several bird species (Fischer 1981; Khera \& Kalsi 1986; Natarajan 1991; Ramachandran 1998; Martinez 2000; Muzaffar 2004).

Indian Roller spent an average of $5.1 \%$ of their diurnal time resting, which differed significantly between time of day, season and habitats. Resting activity varied between time of day and it always peaked (10.3\%) at midday. Earlier, many researchers also found resting to be a major midday activity of birds (Verbeek 1972; Quinlan \& Baldassarre 1984; Losito et al. 1990; Lee 1997; Martinez 2000). Tamisier (1976) suggested that an increase in resting during midday as a mechanism to minimize the heat load on a bird at high environmental temperatures. Sleeping was the major diurnal resting activity for Indian Roller and generally resting on dense trees and electric power lines.

\section{REFERENCES}

Ali, S. \& S.D. Ripley (1983). Handbook of Birds of India and Pakistan. Oxford University Press, Bombay, 737pp.

Altmann, J. (1974). Observational study of behaviour: sampling methods. Behaviour 49: 227-267.

Andrewartha, H.G. \& L.C. Birch (1954). The Distribution and Abundance of Animals. University of Chicago Press, Illinois, 782pp.

Andrewartha, H.G. \& L.C. Birch (1984). The Ecological Web. University of Chicago Press, Chicago, 506pp.

Asokan, S., K. Thiyagesan \& R. Nagarajan (2003). Studies on Merops orientalis Latham 1801 with special reference to its population in Mayiladuthurai, Tamil Nadu. Journal of Environmental Biology 24(4): 477-482.

Asokan, S., A.M.S. Ali \& R. Manikannan (2009). Diet of three insectivorous birds in Nagapattinam District, Tamil Nadu, India - a preliminary study. Journal of Threatened Taxa 1(6): 327-330

Begon, M. \& M. Mortimer (1986). Population Ecology. Siraue Associations, Sunderland, M.A., 163pp.

Chamberlain, D.E., J.D. Wilson \& R.J. Fuller (1999). A comparison of bird populations on organic and conventional farm systems in Southern Britain. Biological Conservation 88: $307-320$

DeGraff, R.M. \& J.M. Wentworth (1986). Avian guild structure and habitat associations in suburban bird communities. Urban Ecology 9: 399-412.

Ding , T., P. Lee \& Y. Lin (1997). Abundance and distribution of birds in four, high elevation plant communities in Yushan National Park, Taiwan. Acta Zoologica Taiwanica 8(1): 5564.

Emlen, J.T. (1970). Habitat selection by birds following a forest fire. Ecology 51(2): 343-345.

Ettinger, A.O. \& J.R. King (1980). Time and energy budgets of the Willow Flycatcher (Empidonax traillii) during the breeding season. Auk 97: 533-546.

Evers, D.C. (1994). Activity budgets of a marked Common Loon (Gavia immer) nesting population. Hydrobiologia 279\&280: 415-420.

Fischer, D.H. (1981). Winter time budgets of Brown Thrashers. Journal of Field Ornithology 52(4): 304-308.

Frederick, R.B. \& E.E. Klaas (1982). Resource use and behavior of migrating Snow Geese. Journal of Wildlife Management 46: 601-614.

Gaston, A.J. (1975). Estimating bird population. Journal of the Bombay Natural History Society 72: 271-283.

Gauthier, G., Y. Bedard \& J. Bedard (1988). Habitat use and activity budgets of Greater Snow Geese in spring. Journal of Wildlife Management 52: 191-201.

Gupta, S. (1976). Indian Rollers, Black Drongos, etc., feeding at night. Newsletter for Birdwatchers 16(9): 13.

Hamilton, A.J., I.R. Taylor \& G. Hepworth (2002). Activity budgets of waterfowl (Anatidae) on a waste-stabilization pond. Emu 102: 171-179.

Holmes, R.T. \& S.K. Robinson (1981). Tree species preferences of foraging insectivorous birds in a northern hardwoods forest. Oecologia 48: 31-35.

James, F.C. (1971). Ordinations of habitat relationships among breeding birds. Wilson Bulletin 83: 215-236.

Johnston, D.W. \& E.P. Odum (1956). Breeding bird populations relation to plant succession on the Piedmont of Georgia. Ecology 37: 50-65.

Jonsson, J.E. \& A.D. Afton (2006). Different time and energy budgets of Lesser Snow Geese in rice-prairies and coastal marshes in Southwest Louisiana. Waterbirds 29: 451-458. 
Khera, S. \& R.S. Kalsi (1986). Diurnal time budgets of the Bank Myna Acridotheres ginginianus (Sturnidae) during prelaying, laying and incubation period. Pavo 25: 25-32.

Lack, D. (1937). The psychological factor in bird distribution. British Birds 31: 130-136.

Lack, D. (1966). Population Studies of Birds. Oxford University Press, London, 341pp.

Lancaster, R.K. \& W.E. Rees (1979). Bird communities and the structure of urban habitats. Canadian Journal of Zoology 57: 2358-2368.

Lee, S. (1997). A time budget study of wintering mallards on the Southern High Plains of Texas, USA. Korean Journal of Biological Science 1: 571-576.

Losito, M.P., R.E. Mirarchi \& G.A. Baldassarre (1990). Summertime activity budget of hatching-year Mourning Doves. Auk 107: 18-24.

Mahabal, A. (1991). Activity-time budget of Indian Myna Acridotheres tristis (Linnaeus) during the breeding season. Journal of the Bombay Natural History Society 90 96-97.

Martinez, C. (2000). Daily activity patterns of Great Bustards Otis tarda. Ardeola 47(1): 57-68.

Mathew, D.N., T.C. Narendran \& V.J. Zacharias (1978). A comparative study of the feeding habits of certain species of Indian birds affecting agriculture. Journal of the Bombay Natural History Society 75(2): 1178-1197.

Menge, B.A. \& J.P. Sutherland (1987). Community regulation: variation in disturbance, competition, and predation in relation to environmental stress and recruitment. American Naturalist 130: 730-757.

Muzaffar, S.B. (2004). Diurnal time-activity budgets in wintering Ferruginous Pochard Aythya nyroca in Tanguar Haor, Bangladesh. Forktail 20: 25-27.

Natarajan, V. (1991). Time budgeting by the Southern Crow-pheasant (Centropus sinensis) at Point Calimere, Tamil Nadu. Journal of the Bombay Natural History Society 90: 92-95.

Odum, E.P. (1950). Bird populations of high lands (North Carolina) plateau in relation to plant succession and avian invasion. Ecology 31: 57-605.

Panicker, K.N. (1978). Ecology of hole nesting birds. Journal of the Bombay Natural History Society 75: 1227-1237.

Paulus, S.L. (1984). Activity budgets of non-breeding gadwalls in Louisiana in winter. Journal of Wildlife Management 46: 483-489.

Paulus, S.L. (1988). Time activity budgets of Mottled Ducks in Louisiana in winter. Journal of wildlife Management 52: 711-718.

Pulliam, H.R. (1988). Sources, sinks and population regulation. American Naturalist 132: $652-661$

Quinlan, E.E. \& G.A. Baldassarre (1984). Activity budgets of non-breeding Greenwinged Teal on Playa lakes in Texas. Journal of Wildlife Management 48: 838-845.

Ramachandran, N.K. (1998). Activity patterns and time budgets of the Pheasant-tailed (Hydrophaslanus chirurgus) and Bronzewinged (Metopidius indicus) Jacanas. Journal of the Bombay Natural History Society 95: 234-245.

Rasmussen, P. \& J.C. Anderton (2005). Birds of South Asia: The Ripley Guide. 2 vols. Smithsonian Institution \& Lynx Editions, Washington, D.C. \& Barcelona, 356pp.

Rodway, M.S. (1998). Activity patterns, diet and feeding efficiency of Harlequin Ducks breeding in northern Labrador. Canadian Journal of Zoology 76: 902-909.

Rosenzweig, M.L. (1991). Habitat selection and population interactions: the search for mechanisms. American Naturalist 137: 5-28.

Santharam, V. (1996). Notes on the mating behaviour of the Indian Roller. Newsletter for Birdwatchers 35: 71.

Schartz, R.L. \& J.L. Zimmerman (1971). The time and energy budget of the male Dickcissel (Spiza americana). Condor 73: 65-67.

Sivakumaran, N. \& K. Thiyagesan (2003). Population, diurnal activity patterns and feeding ecology of the Indian Roller Coracias benghalensis. Zoos' Print Journal 18(5): 1091-1095.

Sokal, R.R. \& F.J. Rohalf (1981). Biometry. W.H. Freeman and Company, New York, $887 p p$.

Svardson, G. (1993). Competition and habitat selection in birds. Oikos 1: 157-174

Tamisier, A. (1976). Diurnal activities of Green-winged Teal and Pintail in Louisiana. Wildfowl 27: 19-32.

Tokeshi, M. (1993). Species abundance patterns and community structure. Advances in Ecological Research 24: 111-186.

van Balen, J.H. (1980). Population fluctuations of the Great Tit and feeding conditions in winter. Ardea 68: 143-164.

Verbeek, N.A.M. (1972). Daily and annual time budget of the Yellow-billed Magpie. Auk 89: $567-582$

Verner, J. (1965). Time budgets of the male Long-billed Marsh Wren during the breeding season. Condor 67: 125-139.
Author Details:

Dr. S. AsoKAN is currently teaching, undertaking and supervising various research activities. $\mathrm{He}$ has produced $7 \mathrm{PhD}$ and 40 MPhil scholars in wildlife biology and zoology. He has published more than 35 research papers in leading national and international journals.

A Mohamed Samsoor Au obtained his MSc degree in Wildlife Biology from A.V.C. College, Mannampandal in 2003 and has been working on various fields of ornithology since 2004

$R$. MANIKANNAN is working as a lecturer and also doing $\mathrm{PhD}$ on 'Diversity of wetland birds in Point Calimere Wildlife Sanctuary'.

G. Thomas Nithiyanandam is working on 'Birds of agro-ecosystem in Nagapattinam District' for a $\mathrm{PhD}$ degree.

Acknowledgements: We thank the Ministry of Environment and Forests (MoEF), Government of India for the financial assistance to undertake field investigations. Authors are thankful to the principal, the management, staff and the Head of the Department of Zoology \& Wildlife Biology, A.V.C. College (Autonomous), Mannampandal, Mayiladuthurai for facilities and encouragement. Thanks are also due to the anonymous reviewers and the subject editor for their very constructive comments and suggestions. 